\title{
Impact of Tillage and Residue Management on Sustainable Food and Nutritional Security
}

\author{
Kumari Aditi $^{1,2 *}$, Girish Chander ${ }^{1}$, P. Laxminarayana ${ }^{2}$, S. P. Wani ${ }^{1}$, \\ S. Narender Reddy ${ }^{2}$ and G. Padmaja ${ }^{2}$ \\ ${ }^{1}$ International Crops Research Institute for Semi-Arid Tropics, \\ Patancheru, Telangana - 502324, India \\ ${ }^{2}$ ProfessorJayashankar Telangana State Agricultural University, \\ Rajendranagar, Telangana - 500030, India \\ *Corresponding author
}

\section{A B S T R A C T}

Keywords

Bio-diversity, Food, Fuel, Fibre, Feed, Soil degradation, Rainfed crops

Article Info

Accepted:

15 September 2019

Available Online:

10 October 2019
A field experiment was conducted during kharif and rabi in 2016-17 and 2017-18 at International Crops Research Institute for the Semi-arid Tropics, Patancheru, Hyderabad to study the influence of tillage practices and residue management practices on yield attributes and yield of maize in maize-based cropping systems under semi-arid tropics. The field experiment was laid out on broad-beds and furrows in a split-split design with four replications under rainfed conditions. Main plot consisted of two tillage practices (minimum tillage and conventional tillage), sub-plot of two crop residue management practices (residue addition and no-residue addition) and sub-sub plot of two cropping systems (Maize-chickpea sequential cropping and maize+pigeonpea intercropping system). The results revealed that equivalent yield, system productivity and nutrient content of maize did not vary significantly due to tillage practices, however, minimum tillage led to considerable yield losses. Among the residue management practices, addition of crop residue recorded significantly higher equivalent yield as compared to no residue addition. System productivity was significantly higher under residue addition and maize-chickpea copping system. Stover nitrogen content was significantly higher under residue addition over no residue addition.

\section{Introduction}

India is endowed with a rich and vast diversity of natural resources, particularly soil, water, weather, multipurpose trees and bio-diversity. To realize the potential of production system on a sustained basis, efficient management of the natural resources is very crucial. With adoption of intensive agriculture to meet the varied growing demands for food, fuel, fibre, feed and fertilizer in the recent years, the natural resources are however, put under 
intense strain resulting in fast degradation and lowering of their production efficiency.

Rainfed areas in India are spread across varied climatic and soil conditions where crop production is constrained by several factors. Traditional cultivation practices such as excessive tillage, harvest and removal of entire biomass, burning of the left-over stubbles in the field for preparation of clean seedbed and open grazing aggravate the soil degradation. As a result, the yield of rainfed crops in these soils is very low.

Conservation agriculture (CA) is often advocated as one of the adaptation and mitigation strategies for the climate change and conservation of natural resources. It comprises of three basic components of minimum tillage, biomass addition and crop rotations with legumes (Thierfelder et al., 2013) which are considered to play major role for addressing the challenges of decline in soil health, water-table, size of land holding and factor productivity, rise in cost of cultivation and above all climate change, which are the stumbling blocks in achieving livelihood security, especially of small farm holders in semi-arid tropics.

Most conservation agriculture practices are regarded as improved soil management practices. Minimum soil disturbance increases water productivity, mulching and crop residues improve water infiltration and planting basins maximize soil moisture buffer capacity. Therefore, CA can play an important role in mitigating climate risk especially in arid and semi-arid regions. However, there are divergent views about the long-term impact of conservation agriculture on crop performance and reclamation of soil health. Even a single tillage event in a long-term no-till soil can result in losses of much of the carbon that had been gained under previous years of no tillage (Conant et al., 2007).
The problem of on-farm burning of crop residues is intensifying in recent years due to shortage of human labour, high cost of removing the crop residues by conventional methods and use of combines for harvesting of crops. Burning of crop residues leads to release of soot particles and smoke causing human and animal health problems. Heat generated from the burning of crop residues elevates soil temperature causing death of active beneficial microbial population, though the effect is temporary, as the microbes regenerate after a few days. Addition of these crop residues on the soil surface may positively influence soil chemical and physical properties. Linkages of soil organic matter and soil $\mathrm{C}$ with soil health and yield are well established and so investments in terms of organic inputs are likely to benefit in sustainable productivity.

Maize is a major coarse cereal crop cultivated in an area of $18.3 \mathrm{~m}$ ha globally, and 7.87 million ha in India. Pigeonpea and chickpea are important legume crops in the drylands covering around 4.8 million ha and 11.0 million ha area globally and around 4.51 million ha and 10.7 million ha in India, respectively. Pigeon pea being deep rooted and slow-growing in its early growth stage, during which the more rapidly growing crop like maize can be conveniently intercropped to utilize the natural resources more efficiently (Willey et al., 1981). Addition of crop residues under this system has enhanced the system productivity and soil health (Saad et al., 2015). Inputs of nitrogen through fallen pigeon pea leaves contribute $75-90 \mathrm{~kg} \mathrm{~N}^{-1}$ which substantially benefits a following maize crop (Sakala et al., 2000). Maize-chickpea cropping sequence is one among the predominant cereal-legume cropping systems being followed in India. Though maize yields are not affected due to photo insensitive nature, the chickpea yields are greatly affected by delayed sowing. Delay in sowing of 
chickpea from middle of November to middle of December reduces the yields from 2.0 to 1.5 tonnes $\mathrm{ha}^{-1}$.

There are divergent views on the impacts of $\mathrm{CA}$ as such and there is limited reliable longterm data. Hence, there is a need for long-term studies on minimum-till and residue addition with different crops and cropping systems in different soils and under various climate conditions. The present experiment was a continuation of a previous experimental set up which started at ICRISAT in 2009. Therefore, the present study entitled "Impact of tillage and residue management on sustainable food and nutritional security" was undertaken with same tillage, residue management practices and cropping systems.

\section{Materials and Methods}

A long-term field experiment was established in kharif/rainy (June-Oct) 2009 season at the ICRISAT on-station farm $\left(17.50^{\circ} \mathrm{N}, 78.26^{\circ} \mathrm{E}\right.$ and altitude $545 \mathrm{~m})$ near Hyderabad, Telangana state, India. The soil of the experimental site is a Vertisol. During the growth period, a total rainfall of $998.7 \mathrm{~mm}$ was received in 56 rainy days during kharif 2016-17 and $1108.4 \mathrm{~mm}$ in 61 rainy days during kharif 2017-18. The field experiment was laid out on broad-beds and furrows (in $1.05 \mathrm{~m}$ wide raised bed followed by $0.45 \mathrm{~m}$ wide furrow) in a split-split design with four replications under rainfed conditions. Main plot consisted of two tillage practices (minimum tillage and conventional tillage), sub-plot of two crop residue management practices (residue addition and no-residue addition) and sub-sub plot of two cropping systems (Maize-chickpea sequential cropping and maize+pigeonpea intercrop). Soil disturbance in minimum tillage plots was restricted to minor refreshing of furrows before the start of kharif/rainy season, while in conventional tillage plots, ploughing of field with chisel plough, mould board plough and ridge and harrow as normal farmers' practice was undertaken. The residues were removed completely from the no-residue addition treatment plots, while entire crop residues were chopped into finer sizes and spread over the beds after end of the crop season in the residue addition plots. Sowing of crop was done with the help of seed-cum-fertilizer drill. Maize hybrid HTM-5401 was intercropped with pigeonpea hybrid ICPH-2671 in the maize+pigeonpea intercropping system. In maize-chickpea sequential cropping system, maize hybrid HTM-5401 was grown in rotation with chickpea variety ICCV-2. The fertilizer schedule adopted for maize crop was 150, 60 and $40 \mathrm{~kg} \mathrm{ha}^{-1}$ of $\mathrm{N}, \mathrm{P}$ and $\mathrm{K}$ respectively and for chickpea was 25 and 50 $\mathrm{kg} \mathrm{ha}^{-1}$ of $\mathrm{N}$ and $\mathrm{P}$ respectively.

Entire dose of phosphorus and potassium were applied as basal in the form of DAP and MOP respectively. Nitrogen in the form of urea after calculating the proportion supplied through DAP was applied in three splits as per schedule i.e., $1 / 3^{\text {rd }} \mathrm{N}$ as basal, $1 / 3^{\text {rd }} \mathrm{N}$ at 30 DAS and remaining $1 / 3^{\text {rd }} \mathrm{N}$ at 60 DAS.

Secondary nutrients $\mathrm{S}$ in the form of gypsum and micronutrient $\mathrm{B}$ in the form of solubor were applied every second year. This study documents the impacts of tillage and residue management during $8^{\text {th }}$ and $9^{\text {th }}$ year of the experiment i.e., during 2016-17 and 2017-18 cropping seasons. For yield estimation, destructive samples were taken in an area of 3 $\mathrm{x} 3$ square metre and yields were extrapolated in $\mathrm{kg}$ per ha.

In respective cropping systems viz. maize chickpea and maize + pigeonpea, yield of chickpea and pigeonpea was converted in to maize grain yield based on their market price prevailing during the season in relation to maize grain yield by using the following formula: 
MEY of Chickpea $\left(\mathrm{kg} \mathrm{ha}^{-1}\right)$

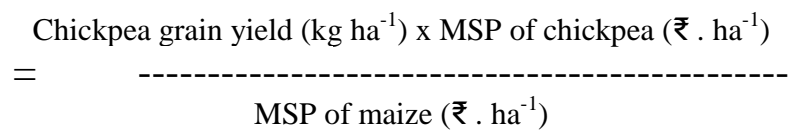

MEY of Pigeonpea $\left(\mathrm{kg} \mathrm{ha}^{-1}\right)$

Pigeonpea grain yield $\left(\mathrm{kg} \mathrm{ha}^{-1}\right) \times$ MSP of Pigeonpea (₹ . ha $\left.{ }^{-1}\right)$ $=$

MSP of maize (₹ . ha $\left.{ }^{-1}\right)$

Where MSP is minimum support price during the cropping year.

The plant samples collected for dry matter production were utilized for chemical analysis which was separated into grain and straw, dried to a constant weight in oven at $65 \pm 5{ }^{\circ} \mathrm{C}$. The dried samples were powdered and used for chemical analysis in Charles Renard Analytical Laboratory at ICRISAT, Patancheru. Total $\mathrm{N}$ and Pin plant materials were determined by digesting the samples with sulphuric acid-selenium. $\mathrm{N}$ and $\mathrm{P}$ in the digests were analyzed using autoanalyzer,(Sahrawatet al., 2002a).System productivity of maize-chickpea sequential cropping system was calculated by using the following equation:

Maize-chickpea system productivity $=(\mathrm{MEY}$ of chickpea + Maize grain yield)/365 Maize+pigeonpea system productivity = (MEY of pigeonpea + Maize grain yield)/365

\section{Results and Discussion}

\section{Maize Equivalent Yield}

Maize equivalent yield did not differ significantly in response to tillage practice during both years and pooled means (Table 1). However, maize equivalent yield differed significantly in response to residue management practice during both the years of study and pooled means. Significantly higher maize equivalent yield was recorded with addition of residue over no residue addition. The percentage increase under residue addition over no residue addition was $18 \%$ and $19 \%$ in 2016-17 and 2017-18, respectively.

Maize equivalent yield tended to be higher under maize-pigeonpea cropping system and was significantly higher during 2017-18 and pooled means over maize-chickpea cropping system.

Addition of residue increased maize equivalent yield by improving the physicochemical and biological properties of soil thereby ensuring healthy plant growth. Reduced evaporation losses and moderated soil temperature might have reduced the fluctuations in water availability to crops and increased yield of individual crops and maize equivalent yield in turn (Ramesh et al., 2016).

\section{System productivity}

Significantly higher system productivity was recorded under residue addition over no residue addition (Table 2). Among the two cropping systems, significantly higher system productivity was recorded under maizechickpea sequence over maize+pigeonpea intercropping system during 2016-17. System productivity was non-significant in response to both the cropping systems during 2017-18.

Higher system productivity under residue addition might be due to improved physicochemical properties of the soil, increased carbon concentration creating favourable conditions for early crop growth in both the cropping systems, consequently leading to efficient photosynthesis and translocation of photosynthates from source to sink resulting in increase in crop biomass. Hence, higher total biomass yield under residue addition could have led to significant increase in system productivity (Kumar and Angadi, 2016). 
Nitrogen and phosphorus content of maize stover

No significant difference was observed in the nitrogen content of maize stover in response to tillage and cropping systems during both years of study (Table 3). However, concentration of nitrogen was found to be significantly higher under residue addition over no residue addition during both years. Concentration of phosphorus remained unaffected due to tillage, residue management and cropping systems during both the years.

Table.1 Effect of tillage and residue management practices on equivalent yield $\left(\mathrm{kg} \mathrm{ha}^{-1}\right)$ of maize in maize-chickpea and maize+pigeonpea cropping systems

\begin{tabular}{|c|c|c|c|c|c|c|}
\hline \multirow[t]{2}{*}{ Treatment } & \multicolumn{6}{|c|}{ Maize Equivalent Yield $\left(\mathrm{kg} \mathrm{ha}^{-1}\right)$} \\
\hline & \multicolumn{2}{|c|}{ 2016-17 } & \multicolumn{2}{|c|}{ 2017-18 } & \multicolumn{2}{|c|}{ Pooled } \\
\hline \multicolumn{7}{|c|}{ Main plot: Tillage } \\
\hline Conventional Tillage & \multicolumn{2}{|c|}{2917} & \multicolumn{2}{|c|}{3301} & \multicolumn{2}{|c|}{3109} \\
\hline Minimum Tillage & \multicolumn{2}{|c|}{2685} & \multicolumn{2}{|c|}{3331} & \multicolumn{2}{|c|}{3008} \\
\hline S.Em \pm & \multirow{2}{*}{\multicolumn{2}{|c|}{121}} & \multicolumn{2}{|c|}{95} & \multicolumn{2}{|r|}{79} \\
\hline $\mathrm{CD}(=\mathbf{0 . 0 5})$ & & & \multicolumn{2}{|c|}{ NS } & \multicolumn{2}{|r|}{ NS } \\
\hline \multicolumn{7}{|c|}{ Sub plot: Residue management } \\
\hline No residue addition & \multicolumn{2}{|c|}{2560} & \multicolumn{2}{|c|}{3024} & \multicolumn{2}{|c|}{2792} \\
\hline Residue addition & \multicolumn{2}{|c|}{3041} & \multicolumn{2}{|c|}{3608} & \multicolumn{2}{|c|}{3325} \\
\hline S.Em \pm & \multirow{2}{*}{\multicolumn{2}{|c|}{$\begin{array}{l}48 \\
164\end{array}$}} & \multirow{2}{*}{\multicolumn{2}{|c|}{$\begin{array}{c}96 \\
331\end{array}$}} & \multicolumn{2}{|r|}{62} \\
\hline $\mathrm{CD}(=\mathbf{0 . 0 5})$ & & & & & \multicolumn{2}{|c|}{213} \\
\hline \multicolumn{7}{|c|}{ Sub-sub plot: Cropping system } \\
\hline Maize-chickpea & \multicolumn{2}{|c|}{2765} & \multicolumn{2}{|c|}{2881} & \multicolumn{2}{|c|}{2823} \\
\hline Maize+pigeonpea & & 336 & & 51 & & 294 \\
\hline S.Em \pm & & 95 & & 57 & & 87 \\
\hline $\mathrm{CD}(\mathrm{P}=\mathbf{0 . 0 5})$ & & JS & & 85 & & 370 \\
\hline Interaction & S.Em \pm & $\begin{array}{c}\mathrm{CD} \\
\mathrm{P}(=0.05)\end{array}$ & S.Em \pm & $\begin{array}{c}\text { CD } \\
\mathrm{P}(=0.05)\end{array}$ & S.Em \pm & $\begin{array}{c}C D \\
\mathrm{P}(=0.05)\end{array}$ \\
\hline MxS & 131 & NS & 141 & NS & 114 & NS \\
\hline MxC & 155 & NS & 189 & NS & 129 & NS \\
\hline $\mathrm{SxC}$ & 106 & NS & 184 & NS & 107 & NS \\
\hline MxSXC & 188 & NS & 264 & NS & 168 & NS \\
\hline
\end{tabular}


Table.2 Effect of tillage and residue management practices system productivity of maize-chickpea and maize+pigeonpea cropping systems.

\begin{tabular}{|c|c|c|c|c|c|c|}
\hline \multirow[t]{2}{*}{ Treatment } & \multicolumn{6}{|c|}{ System productivity $\left(\mathrm{Kg} \mathrm{ha}^{-1}\right.$ year $\left.^{-1}\right)$} \\
\hline & \multicolumn{2}{|c|}{ 2016-17 } & \multicolumn{2}{|c|}{ 2017-18 } & \multicolumn{2}{|c|}{ Pooled } \\
\hline \multicolumn{7}{|c|}{ Main plot: Tillage } \\
\hline Conventional Tillage & \multicolumn{2}{|c|}{35.5} & \multicolumn{2}{|c|}{26.8} & \multicolumn{2}{|c|}{31.2} \\
\hline Minimum Tillage & \multicolumn{2}{|c|}{33.3} & \multicolumn{2}{|c|}{24.2} & \multicolumn{2}{|c|}{28.8} \\
\hline S.Em \pm & \multicolumn{2}{|c|}{0.81} & \multicolumn{2}{|c|}{1.09} & \multicolumn{2}{|c|}{0.92} \\
\hline CD $(=0.05)$ & \multicolumn{2}{|c|}{ NS } & \multicolumn{2}{|c|}{ NS } & \multicolumn{2}{|c|}{ NS } \\
\hline \multicolumn{7}{|c|}{ Sub plot: Residue management } \\
\hline Residue addition & \multicolumn{2}{|c|}{31.0} & \multicolumn{2}{|c|}{23.1} & \multicolumn{2}{|c|}{27.1} \\
\hline No residue & \multicolumn{2}{|c|}{37.9} & \multicolumn{2}{|c|}{27.9} & \multicolumn{2}{|c|}{32.9} \\
\hline S.Em \pm & \multicolumn{2}{|c|}{1.05} & \multicolumn{2}{|c|}{0.40} & \multicolumn{2}{|c|}{0.67} \\
\hline $\mathrm{CD}(=0.05)$ & \multicolumn{2}{|c|}{2.74} & \multicolumn{2}{|c|}{1.39} & \multicolumn{2}{|c|}{2.32} \\
\hline \multicolumn{7}{|c|}{ Sub-sub plot: Cropping system } \\
\hline Miaze-chickpea & \multicolumn{2}{|c|}{35.1} & \multicolumn{2}{|c|}{25.4} & \multicolumn{2}{|c|}{30.3} \\
\hline Maize+pigeonpea & & 3.8 & & & & \\
\hline S.Em \pm & & 72 & & & & \\
\hline $\mathrm{CD}(=0.05)$ & & 21 & & & & \\
\hline Interaction & S.Em \pm & $\begin{array}{c}\text { CD } \\
\mathrm{P}(=0.05)\end{array}$ & S.Em \pm & $\begin{array}{c}C D \\
\mathrm{P}(=0.05)\end{array}$ & S.Em \pm & $\begin{array}{c}C D \\
\mathrm{P}(=0.05)\end{array}$ \\
\hline MxS & 1.4 & NS & 1.2 & NS & 1.14 & NS \\
\hline MxC & 1.1 & NS & 1.3 & NS & 1.04 & NS \\
\hline $\mathrm{SxC}$ & 1.3 & NS & 0.8 & NS & 0.83 & NS \\
\hline MxSxC & 1.7 & NS & 1.5 & NS & 1.34 & NS \\
\hline
\end{tabular}


Table.3 Effect of tillage and residue management practices on nitrogen and phosphorus content of maize stover at harvest in maize-chickpea and maize+pigeonpea cropping systems.

\begin{tabular}{|c|c|c|c|c|c|c|c|c|c|c|c|c|}
\hline \multirow[t]{2}{*}{ Treatment } & \multicolumn{6}{|c|}{ Nitrogen (\%) } & \multicolumn{6}{|c|}{ Phosphorus (\%) } \\
\hline & \multicolumn{2}{|c|}{ 2016-17 } & \multicolumn{2}{|c|}{ 2017-18 } & \multicolumn{2}{|c|}{ Pooled } & \multicolumn{2}{|c|}{ 2016-17 } & \multicolumn{2}{|c|}{ 2017-18 } & \multicolumn{2}{|c|}{ Pooled } \\
\hline \multicolumn{13}{|c|}{ Main plot: Tillage } \\
\hline $\begin{array}{c}\text { Conventional } \\
\text { Tillage }\end{array}$ & \multicolumn{2}{|c|}{0.52} & \multicolumn{2}{|c|}{0.36} & \multicolumn{2}{|c|}{0.44} & \multicolumn{2}{|c|}{0.05} & \multicolumn{2}{|c|}{0.04} & \multicolumn{2}{|c|}{0.05} \\
\hline Minimum Tillage & \multicolumn{2}{|c|}{0.54} & \multicolumn{2}{|c|}{0.51} & \multicolumn{2}{|c|}{0.53} & \multicolumn{2}{|c|}{0.05} & \multicolumn{2}{|c|}{0.05} & \multicolumn{2}{|c|}{0.05} \\
\hline S.Em \pm & \multicolumn{2}{|c|}{0.01} & \multicolumn{2}{|c|}{0.04} & \multicolumn{2}{|c|}{0.02} & \multicolumn{2}{|c|}{0.004} & \multicolumn{2}{|c|}{0.006} & \multicolumn{2}{|c|}{0.002} \\
\hline $\mathrm{CD}(=0.05)$ & \multicolumn{2}{|c|}{ NS } & \multicolumn{2}{|c|}{ NS } & \multicolumn{2}{|c|}{ NS } & \multicolumn{2}{|c|}{ NS } & & IS & & NS \\
\hline & & & & Sub p & ot: Resid & e manager & nent & & & & & \\
\hline $\begin{array}{l}\text { No Residue } \\
\text { addition }\end{array}$ & & 50 & & 39 & & & & 04 & & 04 & & 0.04 \\
\hline Residue addition & & 57 & & 49 & & & & 06 & & 05 & & 0.06 \\
\hline S.Em \pm & 0 & 01 & & 01 & & & & 004 & & 02 & & .003 \\
\hline $\mathrm{CD}(=0.05)$ & & 04 & & 05 & & & & JS & & IS & & NS \\
\hline & & & & Sub-s & lb plot: C & opping sy & stem & & & & & \\
\hline Maize-chickpea & & 52 & & 43 & & & & 05 & & 05 & & 0.05 \\
\hline Maize+pigeonpea & & 54 & & 44 & & & & 05 & & 05 & & 0.05 \\
\hline S.Em \pm & & 03 & & 03 & & & & 002 & & 03 & & .002 \\
\hline $\mathrm{CD}(\mathrm{P}=\mathbf{0 . 0 5})$ & & IS & & IS & & & & JS & & IS & & NS \\
\hline Interaction & S.Em \pm & $\begin{array}{c}C D \\
\mathrm{P}(=0.05)\end{array}$ & $\begin{array}{c}\text { S.Em } \\
\pm\end{array}$ & $\begin{array}{c}C D \\
\mathrm{P}(=0.05)\end{array}$ & S.Em \pm & $\begin{array}{c}C D \\
\mathrm{P}(=0.05)\end{array}$ & S.Em \pm & $\begin{array}{c}C D \\
P(=0.05)\end{array}$ & S.Em \pm & $\begin{array}{c}\mathrm{CD} \\
\mathrm{P}(=0.05)\end{array}$ & $\begin{array}{c}\text { S.Em } \\
\pm\end{array}$ & $\begin{array}{c}\mathrm{CD} \\
\mathrm{P}(=0.05)\end{array}$ \\
\hline MxS & 0.02 & NS & 0.05 & NS & 0.03 & $\mathrm{NS}$ & 0.007 & NS & 0.006 & NS & 0.003 & NS \\
\hline $\mathrm{MxC}$ & 0.03 & NS & 0.05 & NS & 0.03 & NS & 0.006 & NS & 0.007 & NS & 0.003 & NS \\
\hline SxC & 0.03 & NS & 0.03 & NS & 0.02 & NS & 0.005 & NS & 0.004 & NS & 0.003 & NS \\
\hline MxSXC & 0.04 & NS & 0.06 & NS & 0.04 & NS & 0.007 & NS & 0.008 & NS & 0.004 & NS \\
\hline
\end{tabular}


Favourable growth conditions led to improved source and in turn sink capacity of the crop creating higher demands for nutrients. Increased concentration of nutrients with addition of residue can be attributed to better availability. Incorporation of residue improves the fertility and productivity of soil in the long term (Ponnamperuma, 1984). The residue addition provided opportunities for effective recycling of the huge quantities of nutrients in the straw portion of crops. Since nutrient uptake is a function of biomass production, the rapid increase in biomass under residue addition created demand for the available nutrients, thereby leading to higher level of nutrient content (Hiel et al., 2018; Suma et al., 2015; Kumar and Angadi, 2016 and Bahar, 2013).

The study revealed that minimum tillage leads to losses of crop yield in comparison to conventional tillage practices as there is a reduction in plant stand due to compaction of top soil layer. Addition of crop residues proved to be beneficial in improving maize equivalent yield and system productivity by positively influencing soil and plant nutrient content and carbon concentration.

\section{References}

Bahar, F.A. 2013. Relative performance of resource conservation technologies in maize-based cropping system under temperate Kashmir. Trends in Bioscience. 6(1): 43-45.

Conant, R.T., Easter, M., Paustian, K., Swan, A and Williams, S. 2007. Impacts of periodic tillage on soil C stocks: A synthesis. Soil and Tillage Research, 95(1-2): 1-10.

Hiel, M.P., Barbieux, S., Pierreux, J., Olivier, C., Lobet, G., Roisin, C., Garré, S., Colinet, G., Bodson, B and Dumont, B. 2018. Impact of crop residue management on crop production and soil chemistry after seven years of crop rotation in temperate climate, loamy soils. Peer J. 1-23.

Kumar, B.R and Angadi, S.S. 2016. Effect of tillage, mulching and weed management practices on the performance and economics of chickpea. Legume Research: An International Journal. 39(5).

Ramesh, S.C., Rana, S.S and Subehia, S.K. 2016. Effect of tillage, crop rotations, residue and fertilizer management on productivity, profitability and resource use efficiency of maize (Zea mays L.)based cropping systems in north-west Himalayas. Research on Crops. 17(1) $35-40$.

Saad, A. A., Das, T.K., Rana, D. S and Sharma, A. R. 2015. Productivity, resource-use efficiency and economics of maize (Zea mays)-wheat (Triticum aestivum)-greengram (Vigna radiata) cropping system under conservation agriculture in irrigated north-western Indo-Gangetic plains. Indian Journal of Agronomy 60 (4): 502-510.

Sahrawat, K., Kumar, G. R and Murthy, K. 2002. Sulfuric acid-selenium digestion for multi-element analysis in a single plant digest. Communications in Soil Science and Plant Analysis, 33, 37573765 .

Sakala, W.D., Cadisch, G. and Giller, K.E. 2000. Interactions between residues of maize and pigeonpea and mineral $\mathrm{N}$ fertilizers during decomposition and $\mathrm{N}$ mineralization. Soil biology and biochemistry, 32(5): 679-688.

Suma, C., Sharma, K.L., Vidyavathi, S., Munnalal, T.S.K and Rani, K.U. 2016. Effect of conservation tillage, residue and nitrogen levels on soil nitrogen fractions and their contributions in nitrogen uptake in castor (Ricinus communis). Indian Journal of Agricultural Sciences. 86(4): 474-80. 
Thierfelder, C., Mwila, M and Rusinamhodzi, L. 2013. Conservation agriculture in eastern and southern provinces of Zambia: Long-term effects on soil quality and maize productivity. Soil and Tillage Research. 126: 246-258.
Willey, R.W., Rao, M. R. and Natarajan, M., 1981, Traditional cropping systems with Pigeonpea and their improvement. Workshop on Pigeonpea. ICRISAT, Hyderabad, (India).

\section{How to cite this article:}

Kumari Aditi, Girish Chander, P. Laxminarayana, S. P. Wani, S. Narender Reddy and Padmaja, G. 2019. Impact of Tillage and Residue Management on Sustainable Food and Nutritional Security. Int.J.Curr.Microbiol.App.Sci. 8(10): 1742-1750.

doi: https://doi.org/10.20546/ijcmas.2019.810.203 